\title{
Frictional Characteristics of Friction Brake Material Using Cantala Fibers as Reinforcement
}

\author{
Ilham Taufik Maulana ${ }^{1)}$, Eko Surojo ${ }^{2,3)^{*}}$, Nurul Muhayat ${ }^{2)}$ and Wijang Wisnu Raharjo ${ }^{2)}$ \\ 1) Graduate School of Mechanical Engineering, Universitas Sebelas Maret, Surakarta 57126, Indonesia \\ ${ }^{2)}$ Department of Mechanical Engineering, Faculty of Engineering, Universitas Sebelas Maret, Surakarta 57126, Indonesia \\ ${ }^{3)}$ National Center for Sustainable Transportation Technology, Indonesia \\ *Corresponding author: Eko Surojo (esurojo@ft.uns.ac.id)
}

Manuscript received 22 October 2017; accepted 11 June 2018; published 31 July 2018

\begin{abstract}
Friction brake materials are made from a mixture of materials with different properties in order to meet the brake performance requirement. Friction brake material contains a reinforcement fiber that serves to maintain the integrity of the material when subjected to loading. Natural fiber has the potential to be used as a reinforcement material for friction material due to some of its superior characteristics. In this research, friction brake materials using cantala fibers were developed to investigate their frictional characteristics. The volume fraction of the cantala fibers in the specimens was varied from $0 \%, 4 \%, 8 \%$, to $12 \%$ of the total composition of the friction brake material. The manufacturing of the specimen was initiated by mixing the ingredients, followed by cold pressing of the mixture, hot pressing of the preform, and finally post-curing of the specimens. The frictional characteristics of the specimens were evaluated using pin-on-disc tribometer. The result showed that the cantala fibers contributed to the decrease in the coefficient of friction. An increase in contact pressure caused the coefficient of friction to increase, while the increase in sliding speed caused a decrease in the coefficient of friction. The addition of cantala fiber into the composite could increase wear resistance and stabilize the coefficient of friction of the friction brake material.
\end{abstract}

\section{Keywords}

friction brake material, cantala fibers, natural fiber, wear resistance, coefficient of friction

\section{Introduction}

Friction brake materials should have the heat resistance and coefficient of friction as needed in the braking operation [1]. In railway vehicles, there are the types of composite brake blocks termed as "L-type" and "K-type" which present a low friction coefficient of $0.10-0.23$ and a high friction coefficient of $0.20-0.30$, respectively [2]. The previous papers reported that automotive brake pad using brass fiber and steel fiber revealed a friction coefficient of 0.35-0.45 [3] and 0.38-0.59 [4], respectively. The brake materials consist of many ingredients that are mixed according to the prescribed formulation, since the amount of each ingredient will determine its mechanical properties. The interaction between each ingredient and its counterpart at contact surface influences the coefficient of friction of the brake material. When contact between the brake material and disc brake rotor (or wheel tread) occurs, the reinforcement fiber forms primary contact plateau and then produces nucleation of the secondary contact plateau [5]. The increase in contact pressure during the braking process correlates with the forming of primary contact plateau, which causes the coefficient of friction to increase [6]. In addition to the material composition of brake material and contact pressure, sliding speed also affects the coefficient of friction. Regarding the friction brake material using $\mathrm{Cu}$ and $\mathrm{Al}$ as filler, it was found that the coefficient of friction increases with the increase in sliding speed [7].

In the past, asbestos was widely used as reinforcement in friction brake materials. Asbestos is chosen as reinforcement material due to its ability to be used in high temperature $\left(500^{\circ} \mathrm{C}\right)$ and its wear-resistant property [8]. The advantages owned by asbestos are not directly proportional to the health effects it causes. The addition of asbestos to the mixture of the brake pad composite causes a problem in the human respiratory system [9]. Therefore, due to the adverse impacts, some research has been conducted to find a substitute. Some materials have been researched as a possible substitute for asbestos, such as glass, aramid, potassium titanate, and metallic materials [10].

Natural fiber can be one of the alternatives to apply as reinforcement for friction brake material since it has characteristics such as high mechanical properties, low cost, and eco-friendliness [11]. To date, natural fiber is predominantly used as a structural strengthening material, such as a car 

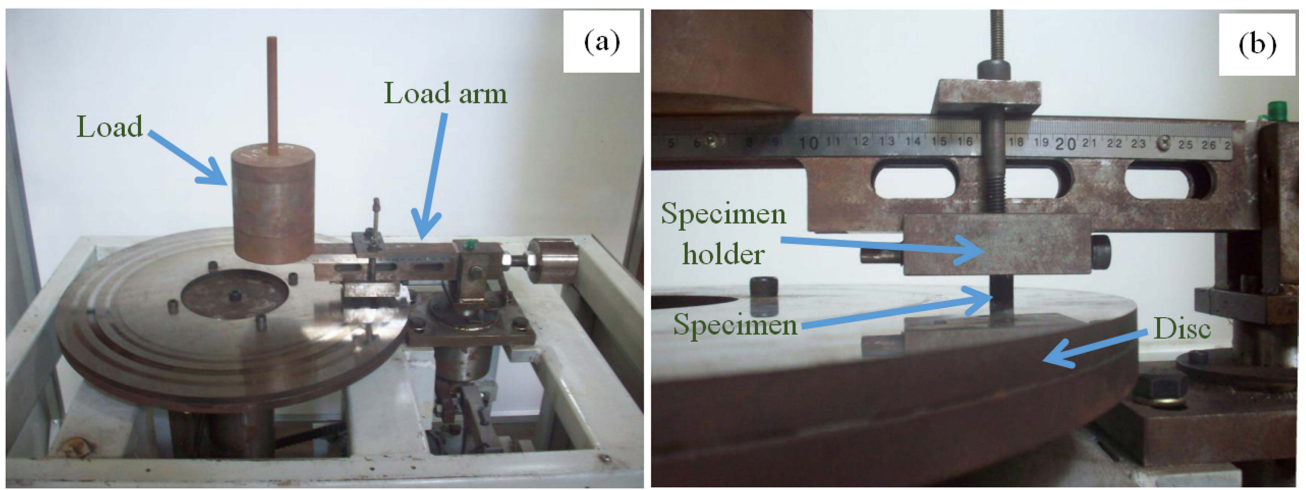

Fig. 1 Pin-on-disc tribometer: (a) test set-up, (b) detail view of contact between pin and disc

body [12]. There are still few studies on natural fiber as a friction material. Some research has been conducted using the powdered form of natural fiber (sugarcane fiber [13], banana peel [14], palm kernel [15], and periwinkle cells [16]) for friction material. This article discusses the development of cantala fiber in the form of short fibers as the reinforcement material for the friction brake composite. Cantala fiber is a natural fiber, which is obtained from Agave cantala Roxb. This kind of plant is grown in East Java, Central Java, Yogyakarta, West Java, and North Sumatera, Indonesia. Cantala fiber has $1.056 \mathrm{gr} / \mathrm{cm}^{3}$ of density level, 3.37-8.41\% hemicelluloses content, $64.21-65.50 \%$ cellulose content, $7.88-9.43 \%$ lignin, and $11.57 \%$ water [17]. It contains cellulose amounting for more than $50 \%$ so that it can be developed as a polymer composite-strengthening material [18]. However, it also has some weaknesses such as the low value of adhesion and thermal stability, as well as its high water absorption tendency $[19,20]$. The weaknesses found in cantala fiber can be solved by treating it with alkaline [21]. In this research, the coefficient of friction of the composite with variations of the volume fraction of cantala fiber and braking condition was studied.

\section{Experimental method}

Before use as a reinforcement fiber for friction brake material, alkaline treatment was applied to the cantala fiber. The process was conducted in several stages, with the order as follows: drying at $110^{\circ} \mathrm{C}$ for 45 minutes, soaking in $5 \% \mathrm{NaOH}$ solution for 4 hours, washing with clean water, drying for one day without being exposed to direct sunlight and then heating at $70^{\circ} \mathrm{C}$ for 10 hours. Fibers that had undergone alkaline treatment were cut in $3 \mathrm{~mm}$ length.

The specimen manufacturing consisted of several stages, started with mixing powdery ingredients by using a blender until homogenous. After that, cantala fiber was added to the mixture and mixed again until homogenous, as in the previous process. The specimen had compositions of 5\% NBR, 25\% graphite, $3 \%$ fly ash, $10 \%$ cashew dust, and $25 \%$ phenolic resin, while the volume fraction for cantala fiber and $\mathrm{CaCO}_{3}$ was subject to variation as shown in Table 1, so that a $100 \%$ total

Table 1 Volume fraction variations for cantala fiber and $\mathrm{CaCO}_{3}$

\begin{tabular}{ccccc}
\hline \multirow{2}{*}{ Materials } & \multicolumn{4}{c}{ \% Volume for specimen code: } \\
\cline { 2 - 5 } & CF0 & CF4 & CF8 & CF12 \\
\hline Cantala fiber & 0 & 4 & 8 & 12 \\
$\mathrm{CaCO}_{3}$ & 32 & 28 & 24 & 20 \\
\hline
\end{tabular}

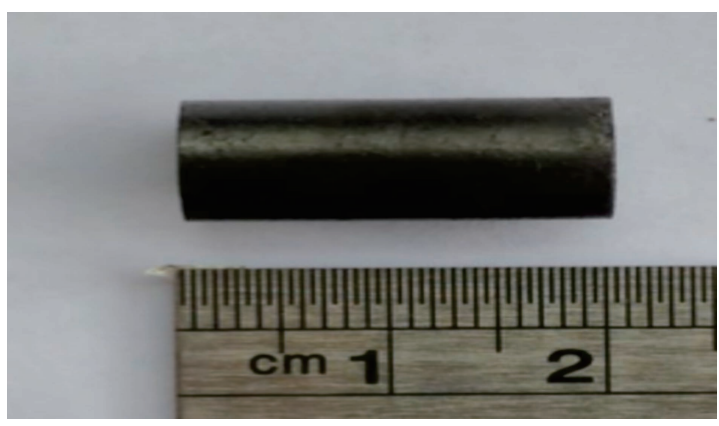

Fig. 2 Specimen size of friction testing

percentage was obtained. Compensation by $\mathrm{CaCO}_{3}$ material is because $\mathrm{CaCO}_{3}$ serves as a filler and used in a large proportion in the specimen that does not have a significant effect on the coefficient of friction [7].

The mixture of the composite specimen was loaded into a cavity mold and cold pressed at a pressure of $40 \mathrm{MPa}$ for 10 minutes. Cold pressing had the purpose of molding the specimen to be easily inserted into the mold when the hot press process was conducted. The preform was put into the hot press mold at a temperature of $160^{\circ} \mathrm{C}$ and then pressed at a pressure of $40 \mathrm{MPa}$ for 10 minutes. Finally, the specimen was post-cured to enhance its mechanical and thermal properties. The postcuring process was conducted in several stages, with the order as follows: heating from room temperature $\left(29^{\circ} \mathrm{C}\right)$ until $140^{\circ} \mathrm{C}$ for 1 hour, heating from $140^{\circ} \mathrm{C}$ until $180^{\circ} \mathrm{C}$ for 6 hours, and then cooling down until room temperature.

Friction testing was performed by using pin-on-disc tribometer as shown in Fig. 1. The test specimen (Fig. 2) was installed on the specimen holder and given some weight on load arm to obtain normal force as desired. The rotor disc of DIN $X$ $153 \mathrm{CrMoV} 12$ steel with a hardness of $54 \mathrm{RC}$ and a roughness of $0.43-1.37 \mu \mathrm{m}$ was used as the mating counterface. The electric motor speed was set through the control panel. The motor rotation would rotate the disc, which then would give friction to the specimen. During the friction testing was performed, a data acquisition system consisting of load cell and computer was used to record friction force. The coefficient of friction $(\mathrm{CoF})$ was calculated by using Eq. (1).

$$
\mathrm{CoF}=\frac{F_{f}}{N}
$$

where $F_{f}$ is the friction force and $N$ is the normal force.

The testing process was started by rubbing the specimen surface to the disc surface until occurring wear on the entire contact area of the specimen and followed by cleaning of the 
Table 2 Variation of friction testing parameter

\begin{tabular}{ccc}
\hline Testing variations & Sliding speed $(\mathrm{m} / \mathrm{s})$ & Contact pressure $(\mathrm{MPa})$ \\
\hline Variation A & $3,6,9,12$ & $0.25,1$ \\
Variation B & 3,12 & $0.25,0.5,0.75,1$ \\
\hline
\end{tabular}

surface of specimen and disc. This procedure was performed to obtain uniform contact between the specimen surface and the disc. After that, the specimen was subjected to friction testing to measure the coefficient of friction. The contact pressure and sliding speed were set in accordance with the variation as shown in Table 2. Testing was conducted on 2 specimens for each composition variation (as shown in Table 1), tested 3 times each. Meanwhile, the testing to measure specific wear was conducted at a contact pressure of $1 \mathrm{MPa}$ with sliding speed of $12 \mathrm{~m} / \mathrm{s}$ and sliding distance of $2450 \mathrm{~m}$. Meanwhile, the specific wear $(W)$ was calculated by using Eqs. (2) and (3).

$$
\begin{array}{ll}
W=\frac{V_{L}}{N \cdot L} & \left(\mathrm{~mm}^{3} / \mathrm{N} \cdot \mathrm{m}\right) \\
V_{L}=V_{1}-V_{2} & \left(\mathrm{~mm}^{3}\right)
\end{array}
$$

where $V_{L}$ is volume loss, $L$ is sliding distance, $V_{1}$ is specimen volume before testing, and $V_{2}$ is specimen volume after testing.

\section{Results and discussion}

3.1 Physical and mechanical properties of cantala fiber

Figures 3 and 4 show the cantala fiber used in this research and fiber surface, respectively. There was a difference between untreated cantala fiber and alkaline-treated cantala fiber. The surface of untreated fiber looked dirtier than that of alkalinetreated one, since the alkaline treatment can remove dirt and hemicelluloses from the fiber surface [22]. In addition to removing dirt and hemicelluloses, alkaline treatment in fiber increased the fiber density and decreased the fiber volume [23].

The tensile strength of the cantala fiber is shown in Table 3. It shows that the alkaline-treated cantala fiber had a higher tensile strength compared to the untreated one. This result indicates that cantala fiber treated with $\mathrm{NaOH}$ alkaline had a high tensile strength because of its high cellulose content. This statement is supported by other research stating that fibers of high cellulose content with strong hydrogen bonds have high tensile strength [21].

Figure 5 shows the thermogravimetric analysis of the untreated cantala fiber and alkaline-treated cantala fiber. It shows that there was a difference between untreated cantala fiber and the alkaline-treated one. Degradations on cantala fiber with and without alkali treatment have 3 steps. First, during $30-200^{\circ} \mathrm{C}$, both degradations occurred at $150^{\circ} \mathrm{C}$, decreasing $9 \%$ of the weight of the fiber without alkali treatment. Second, during $200-300^{\circ} \mathrm{C}$, the fiber with alkali treatment had a weight reduction amount of $20 \%$, and the fiber without treatment had $28 \%$. The reduction of weight on the fiber without treatment

Table 3 Mechanical properties of cantala fiber

\begin{tabular}{cc}
\hline Material & Tensile strength (MPa) \\
\hline Untreated cantala fiber & 241 \\
Alkaline-treated cantala fiber & 268 \\
\hline
\end{tabular}
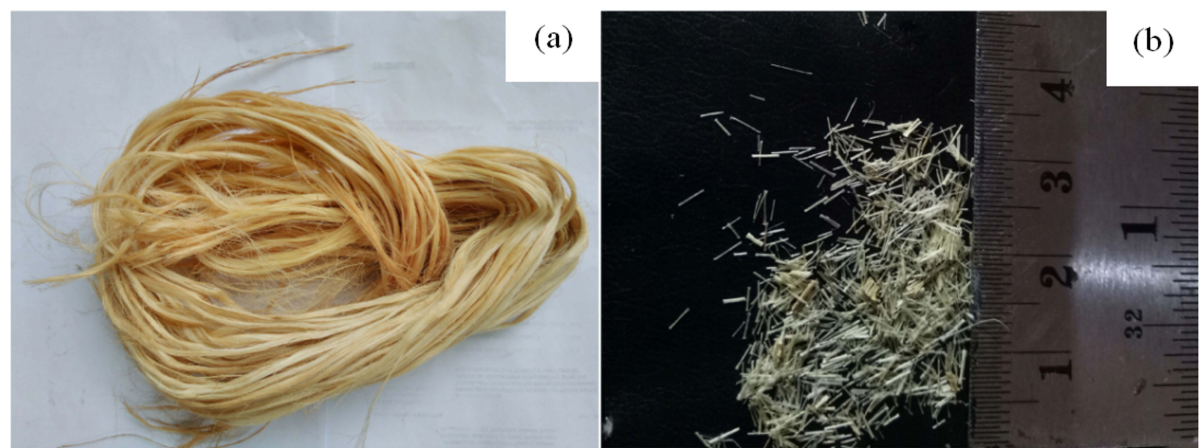

Fig. 3 Cantala fiber: (a) untreated fiber, (b) alkaline-treated fiber (and after cut to length of $3 \mathrm{~mm}$ )
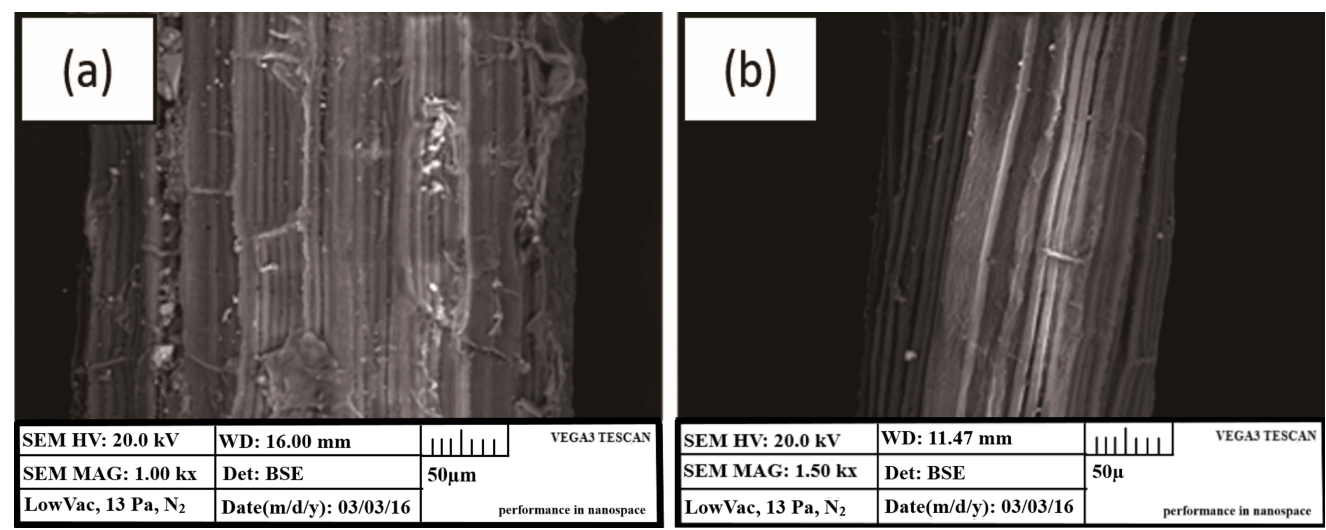

Fig. 4 Cantala fiber surface: (a) untreated fiber, (b) alkaline-treated fiber 


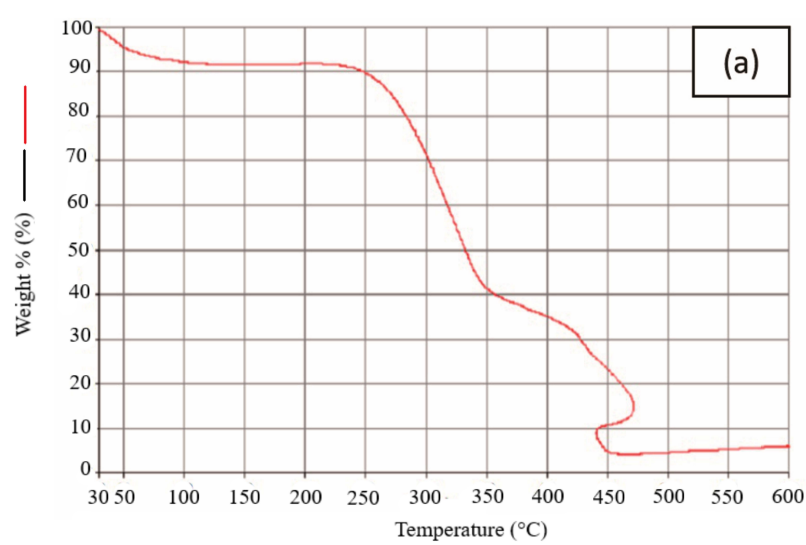

Temperature $\left({ }^{\circ} \mathrm{C}\right)$

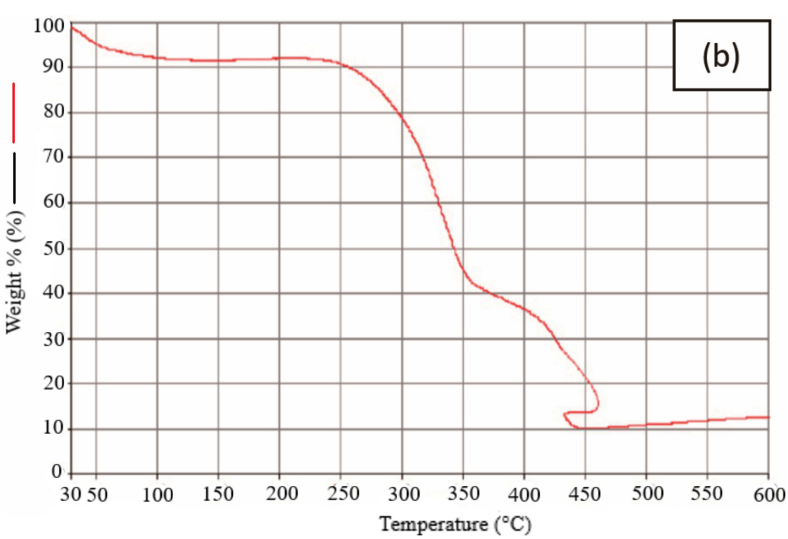

(b) alkaline-treated fiber occurred at $247^{\circ} \mathrm{C}$, whereas the fiber with alkali treatment had a weight reduction at $253^{\circ} \mathrm{C}$. Third, during $300-450^{\circ} \mathrm{C}$, both fibers had their weight decreasing quickly until decomposed at $450^{\circ} \mathrm{C}$. The alkaline treatment of the cantala fiber could remove heat-sensitive amorphic materials and therefore cause thermal decomposition at a higher temperature [24].

Figure 6 shows the relation of volume fraction of cantala fiber against flexural strength of the friction brake composite. Figure 6 explains that the flexural strength of friction brake composite increases with the increasing volume fraction of the cantala fiber. The flexural strength increased with the increase in fiber content because fiber has a high mechanical strength [25]. The addition of cantala fiber can increase an applied load that is transmitted from the matrix phase to the fibers. However, it is also affected by the magnitude of the interfacial bond between the fiber and the matrix phase.

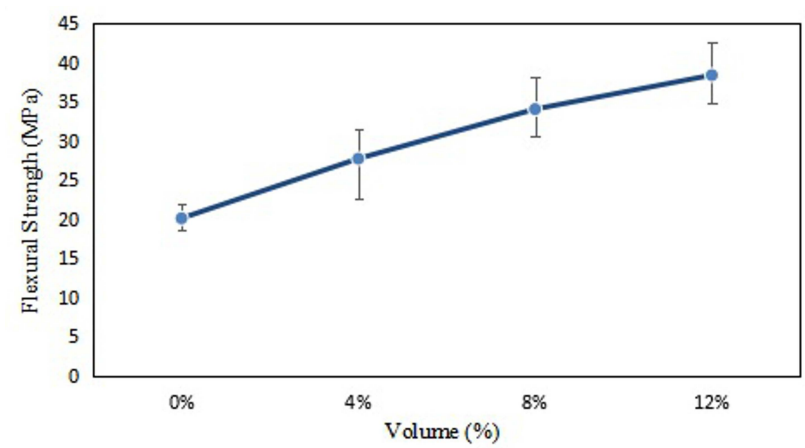

Fig. 6 Effect of \% volume of cantala fiber on flexural strength of composite specimen
3.2 Effect of contact pressure and cantala fiber on coefficient of friction

The coefficient of friction testing result is shown in Fig. 7. It shows that at a sliding speed of $3 \mathrm{~m} / \mathrm{s}$ and $12 \mathrm{~m} / \mathrm{s}$, the coefficient of friction increased with the increasing contact pressure. The increase in the coefficient of friction occurred at all composition variations. The pressure was one of the parameters that are influential to the coefficient of friction, since the increasing contact pressure caused the actual contact area at the interface between specimen and disc to be larger. The larger actual contact area caused an increase in friction force so that the coefficient of friction was higher [26]. The comparison between Fig. 7 (a) and (b) revealed that the changing of the coefficient of friction due to the contact pressure variation at a sliding speed of $12 \mathrm{~m} / \mathrm{s}$ was larger than that at a sliding speed of $3 \mathrm{~m} / \mathrm{s}$.

This result also shows the decrease of the coefficient of friction with the increase in the volume fraction of the fiber, since the cantala fiber particles were generated between the brake composite and disc surface during the friction process. The increasing volume fraction of fiber caused the fiber particles generated by the friction to be higher in amount. The fiber particles would be trapped between the brake composite and disc surface, which would lead to a higher chance of disc slipping. The increasing fiber particle amount rolling between the contact layer of disc and brake composite would decrease the coefficient of friction. Other research reported that the value of coefficient of friction decreased with the increase in volume fraction of rice husk [27] and aramid fiber [28]. Figure 7 shows that the cantala fiber was also influential to the slope of the coefficient of friction as contact pressure function, in which the higher fiber percentage caused the slope to decrease. This was evident at the $3 \mathrm{~m} / \mathrm{s}$ friction speed (Fig. 7 (a)). The decrease in the slope of the coefficient of friction indicated that the coefficient
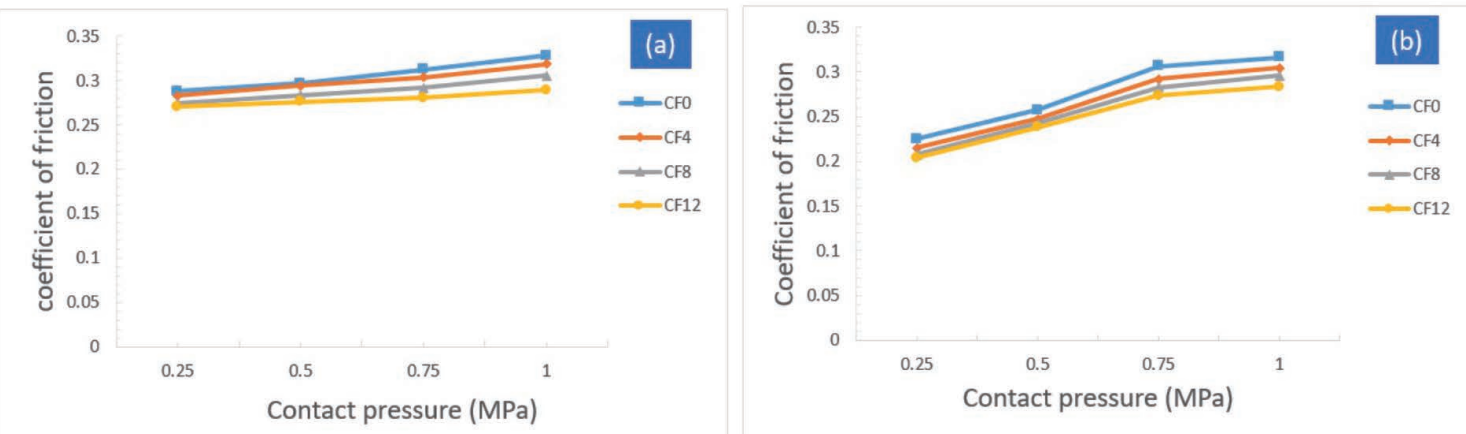

Fig. 7 Effect of contact pressure and cantala fiber on coefficient of friction at a sliding speed of: (a) $3 \mathrm{~m} / \mathrm{s},(\mathrm{b}) 12 \mathrm{~m} / \mathrm{s}$ 

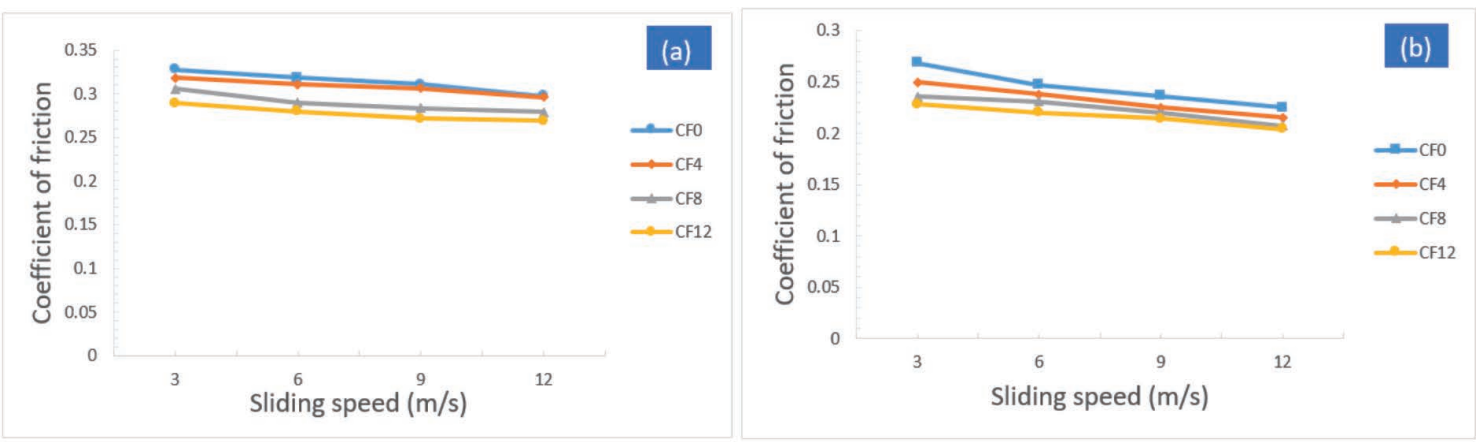

Fig. 8 Effect of sliding speed and cantala fiber on coefficient of friction at a contact pressure of: (a) $1 \mathrm{MPa}$, (b) $0.25 \mathrm{MPa}$

of friction was increasingly insensitive to the contact pressure change. This shows that the cantala fiber was able to improve the stability of the coefficient of friction against a change in contact pressure, especially at the friction speed of $3 \mathrm{~m} / \mathrm{s}$.

3.3 Effect of sliding speed and cantala fiber on coefficient of friction

The result of coefficient of friction testing is shown in Fig. 8. The coefficient of friction decreased with the increase in sliding speed. The decrease occurred in all brake composition variations. This phenomenon was caused by the increase in sliding speed, which resulted in the increase in specimen temperature at the friction surface, so that the shear strength of composite decreased and the possibility of forming oxides on contact surface increased. The decrease in shear strength of the composite material and a specific oxide on contact surface that have lubricating characteristics caused the decrease in friction force [29].

Figure 8 also shows that the cantala fiber influenced the slope, in which the higher the percentage of fiber was, the lower the slope would be, and it was apparent at a contact pressure of $0.25 \mathrm{MPa}$ (Fig. 8). The smaller slope of the coefficient of friction value indicated that the coefficient of friction of the composite was not sensitive to the variation in sliding speed.

\subsection{Effect of cantala fiber on specific wear}

The result of specific wear testing is shown in Fig. 9. The specific wear decreased with the increase in the volume fraction of the cantala fiber. The specific wear is related to the value of the coefficient of friction. An increase in the volume fraction of the cantala fiber caused the composite's coefficient of friction to decrease. This condition led to the increase in wear resistance. This phenomenon occurs because the mechanical properties of the fiber after mixing with other materials improved and produced better shear strength. The more fiber bonds there are with the matrix, the more the specific wear of the friction brake composite decreases. Figure 10 shows the EDS (Energy Dispersive Spectroscopy) analysis of wear debris generated by the friction between the disc and the composite. The analysis showed that elements most commonly found in the particles were C (37\%) and O (43\%). The elements were originated from ingredients of the specimen such as $\mathrm{CaCO}_{3}$, graphite, cantala fiber and phenolic resin. There were a few elements of $\mathrm{Cu} 0.78 \%$, Cr $1.40 \%$, and V $0.14 \%$, which probably came from particles of the disc that was worn out during friction.

\subsection{Microstructure of the worn surface}

Friction between the disc and composite resulted in contact plateau in various sizes and sliding direction, as shown in Fig.

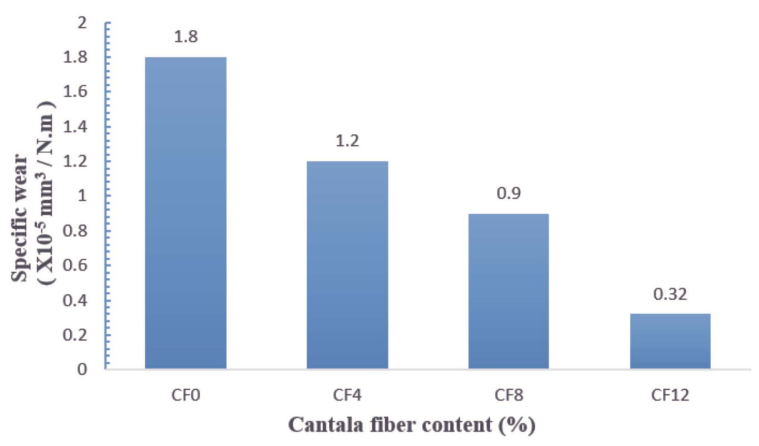

Fig. 9 Effect of cantala fiber on specific wear

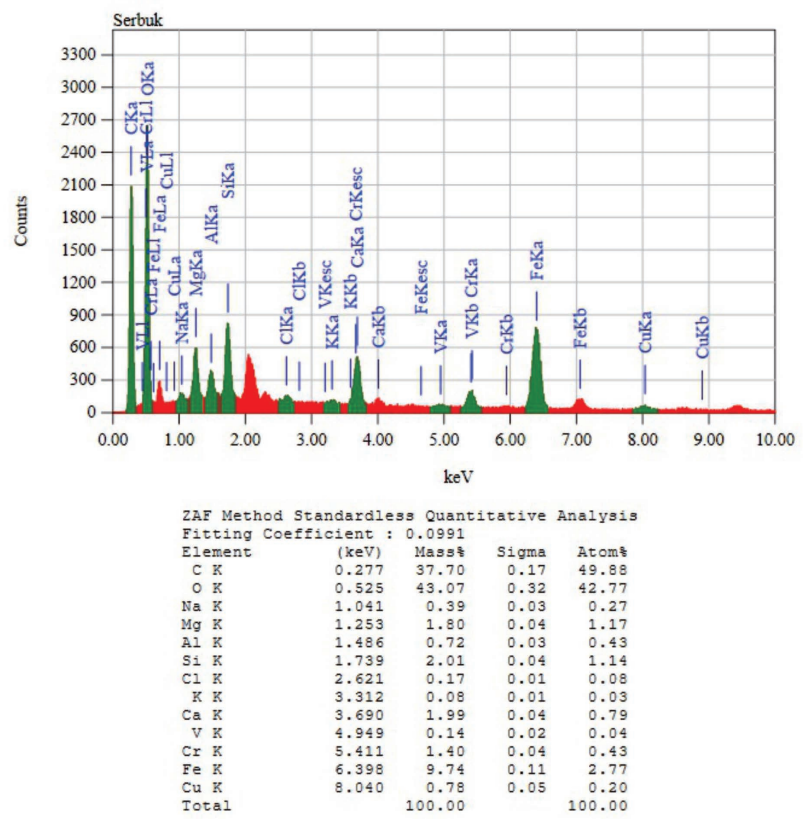

Fig. 10 EDS analysis of wear debris on CF12 specimen

11. It indicated that the friction did not occur on all the surfaces of the specimen. In addition to showing the contact plateau, Fig. 11 reveals the elements and compounds on the surfaces of specimen composite such as carbon, calcium carbonate, magnesium, and silica. Figure 12 shows the result of the SEM (Scanning Electron Microscopy) observation of the composite surface in accordance with the cantala fiber variations. A difference was apparent among the composite surfaces with $0 \%, 4 \%, 8 \%$, and $12 \%$ fiber content. From SEM, the fibers within the brake composite surface can be observed clearly, especially 
on the composite with $12 \%$ fiber content. The observation supported the previously reported wear testing result, which showed that the coefficient of friction decreased along with the increase in glass fiber content [27].

Figure 13 shows the fibers bonded inside matrix in parallel position and are perpendicular to the friction surface. The fiber in parallel position is more susceptible to damage to form wear debris than the fiber in perpendicular position. The fiber in parallel position will detach from the matrix after the matrix wear depth reaches approximately half of the diameter of the fiber [30]. There were some fibers which had apparently been successful in forming interfacial bonds with the matrix as shown in Fig. 13. However, there were also some fibers which failed to form interfacial bonds with the matrix. This phenomenon was

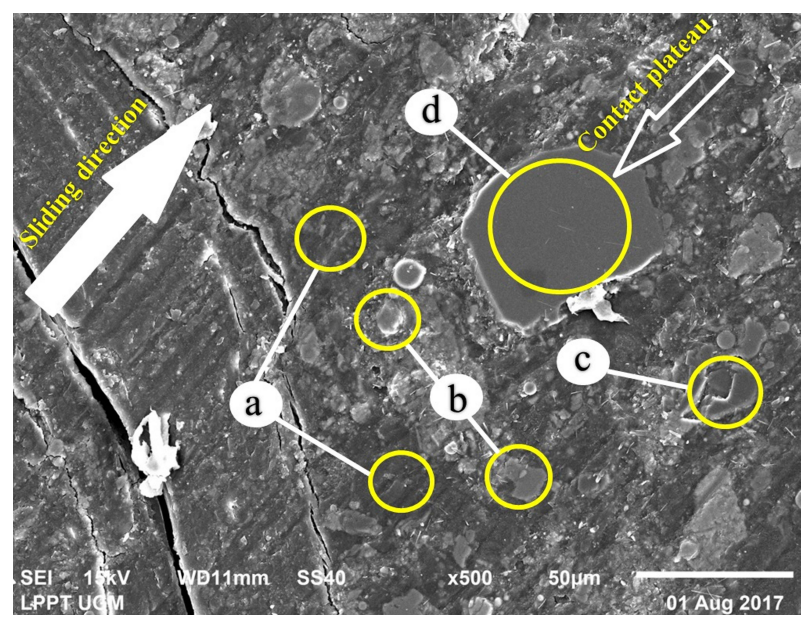

Fig. 11 SEM result on surface of CF12 specimen after tested at a contact pressure of $1 \mathrm{MPa}$ with a sliding speed of 12 $\mathrm{m} / \mathrm{s}$ : (a) carbon, (b) calcium carbonate, (c) magnesium oxide, and (d) silica
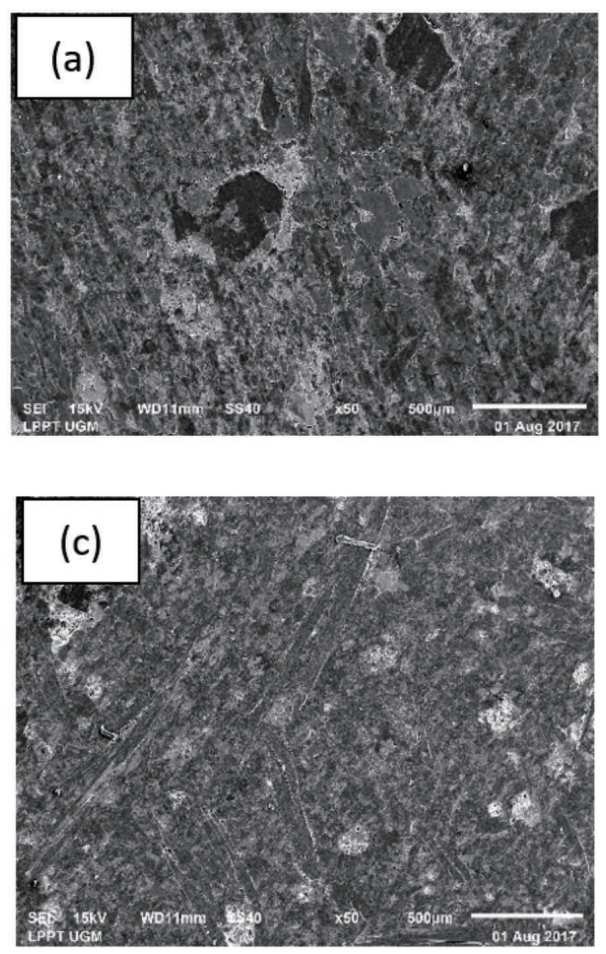

Fig. 12 Worn surface of specimen: (a) CF0, (b) CF4, (c) CF8, (d) CF12

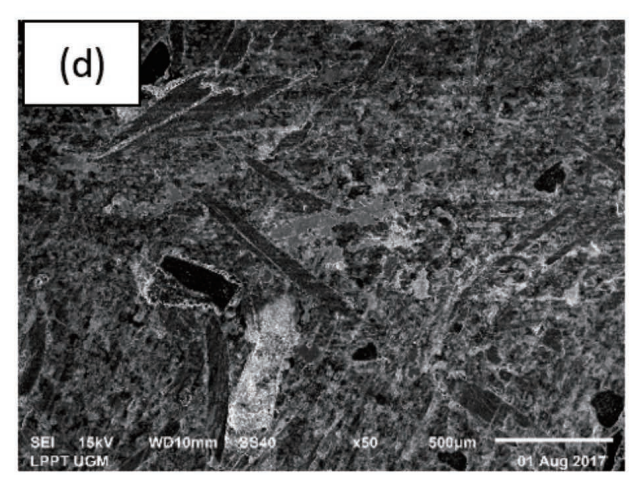

characterized by the existence of gaps between the surface of the fiber and the matrix. The interfacial bonds formed between matrix and fibers affected the characteristics of the composite. This resulted from the treatment applied to the fiber before composite manufacturing. It was also possible that the gaps between the surface of the fibers and the matrix as shown in Fig. 13 was caused by fiber debonding due to friction between the specimen and the disc during the friction testing.

\section{Conclusions}

Based on the discussion of the effect of cantala fibers on the frictional characteristics of the composites, the conclusions thus can be formulated as follows:

a. Cantala fibers affected the frictional characteristic of the friction brake composite. The coefficient of friction decreased as the volume fraction of the cantala fiber increased.

b. The coefficient of friction of the friction brake composite that used cantala fibers as reinforcement was affected by the

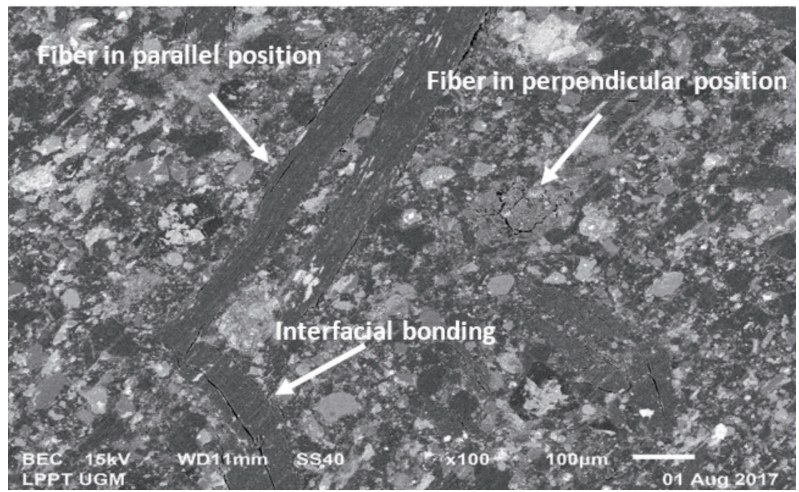

Fig. 13 Worn surface showing position of cantala fiber to the friction surface

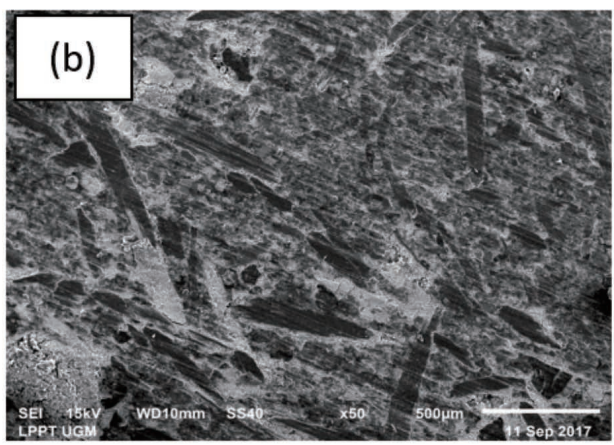


braking condition. The friction brake composite increased the coefficient of friction as the contact pressure increased. Meanwhile, it decreased coefficient of friction as the sliding speed increased.

c. Cantala fibers improved the stability of the coefficient of friction and the wear resistance of the composite.

\section{Acknowledgement}

The research was supported by the Ministry of Research, Technology, and Higher Education of the Republic of Indonesia through the Graduate Research Team Grant (PTP) with Contract No. 873/UN27.21/PP/2017, and USAID through Sustainable Higher Education Research Alliances (SHERA) Program Centre for Collaborative (CCR) National Center for Sustainable Transportation Technology (NCSTT) with Contract No. IIE00000078-ITB-1.

\section{References}

[1] Eriksson, M., Bergman, F. and Jacobson, S., "On the Nature of Tribological Contact in Automotive Brakes," Wear, 252, 1-2, 2002, 26-36.

[2] Vakkalagadda, M. R. K., Srivastava, D. K., Mishra, A. and Racherla, V., "Performance Analyses of Brake Blocks Used by Indian Railways," Wear, 328-329, 2015, 64-76.

[3] Kchaou, M., Sellami, A., Elleuch, R. and Singh, H., "Friction Characteristics of a Brake Friction Material under Different Braking Conditions," Materials and Design, 52, 2013, 533-540.

[4] Verma, P. C., Ciudin, R., Bonfanti, A., Aswath, P., Straffelini, G. and Gialanella, S., "Role of the Friction Layer in the High-Temperature Pin-on-Disc Study of a Brake Material," Wear, 346-347, 2016, 56-65.

[5] Eriksson, M. and Jacobson, S., "Tribological Surfaces of Organic Brake Pads," Tribology International, 33, 12, 2000, 817-827.

[6] Eriksson, M., Bergman, F. and Jacobson, S., "Surface Characterisation of Brake Pads after Running under Silent and Squealing Conditions," Wear, 232, 2, 1999, 163-167.

[7] Kumar, M. and Bijwe, J., "Non-Asbestos Organic (NAO) Friction Composites: Role of Copper; Its Shape and Amount," Wear, 270, 3-4, 2011, 269-280.

[8] Pye, A. M., "A Review of Asbestos Substitute Materials in Industrial Applications," Journal of Hazardous Materials, 3, 2, 1979, 125-147.

[9] Blau, P. J., "Compositions, Functions, and Testing of Friction Brake Materials and Their Additives," Technical Report ORNL/TM2001/64, Oak Ridge National Laboratory, 2001.

[10] AL-Oqla, F. M. and Sapuan, S. M., "Natural Fiber Reinforced Polymer Composites in Industrial Applications: Feasibility of Date Palm Fibers for Sustainable Automotive Industry," Journal of Cleaner Production, 66, 2014, 347-354.

[11] Mustafa, A., Abdollah, M. F. B., Shuhimi, F. F., Ismail, N., Amiruddin, H. and Umehara, N., "Selection and Verification of Kenaf Fibres as an Alternative Friction Material Using Weighted Decision Matrix Method," Materials and Design, 67, 2015, 577-582.

[12] Witayakran, S., Smitthipong, W., Wangpradid, R., Chollakup, R. and Clouston, P. L., "Natural Fiber Composites: Review of Recent Automotive Trends," Reference Module in Materials Science and Materials Engineering, 2017, DOI: 10.1016/B978-0-12-8035818.04180-1.

[13] Aigbodion, V. S., Akadike, U., Hassan, S. B., Asuke, F. and Agunsoye, J. O., "Development of Asbestos - Free Brake Pad Using Bagasse," Tribology in Industry, 32, 1, 2010, 12-18.

[14] Idris, U. D., Aigbodion, V. S., Abubakar, I. J. and Nwoye, C. I., “EcoFriendly Asbestos Free Brake-Pad: Using Banana Peels," Journal of
King Saud University-Engineering Sciences, 27, 2, 2015, 185-192, http://dx.doi.org/10.1016/j.jksues.2013.06.006.

[15] Tahir, N. A. M, Abdollah, M. F. B., Hasan, R. and Amiruddin, H., "The Effect of Temperature on the Tribological Properties of Palm Kernel Activated Carbon-Epoxy Composite," Tribology Online, 10, 6, 2015, 428-433.

[16] Amaren, S. G., Yawas, D. S. and Aku, S. Y., "Effect of Periwinkles Shell Particle Size on the Wear Behavior of Asbestos Free Brake Pad," Results in Physics, 3, 2013, 109-114.

[17] Raharjo, W. W., Sukanto, H. and Anwar, M., "Effect of Soaking Time in Alkali Solution on the Interfacial Shear Strength of Cantala Fiber/ Recycled HDPE Composites," Materials Science Forum, 827, 2015, 375.

[18] Palungan, M. B., Soenoko, R., Irawan, Y. S. and Purnowidodo, A., "Mechanical Properties of King Pineapple Fiber (Agave Cantula Roxb) as a Result of Fumigation Treatment," Australian Journal of Basic and Applied Sciences, 9, 2015, 560- 563.

[19] Dittenber, D. B. and GangaRao, H. V. S., "Critical Review of Recent Publications on Use of Natural Composites in Infrastructure," Composites Part A: Applied Science and Manufacturing, 43, 8, 2012, 1419-1429.

[20] Bledzki, A. K. and Gassan, J., "Composites Reinforced with Cellulose Based Fibres," Progress in Polymer Science, 24, 2, 1999 , 221-274.

[21] Raharjo, W. W, Soenoko, R., Irawan, Y. S. and Suprapto, A., “The Influence of Chemical Treatments on Cantala Fiber Properties and Interfacial Bonding of Cantala Fiber/Recycled High Density Polyethylene (rHDPE)," Journal of Natural Fibers, 15, 1, 2018, 98111, DOI: 10.1080/15440478.2017.1321512.

[22] Boopathi, L., Sampath, P.S. and Mylsamy, K., “Investigation of Physical, Chemical and Mechanical Properties of Raw and Alkali Treated Borassus Fruit Fiber," Composites Part B: Engineering, 43, 8, 2012, 3044-3052.

[23] Orue, A., Jauregi, A., Peña-Rodriguez, C., Labidi, J., Eceiza, A. and Arbelaiz, A., "The Effect of Surface Modifications on Sisal Fiber Properties and Sisal/Poly (Lactic Acid) Interface Adhesion," Composites Part B: Engineering, 73, 2015, 132-138.

[24] Singha, A. S. and Rana, A. K., "Effect of Aminopropyltriethoxysilane (APS) Treatment on Properties of Mercerized Lignocellulosic Grewia Optiva Fiber," Journal of Polymers and the Environment, 21, 1, 2013, 141-150.

[25] Lee, J. H., Cho, B. and Choi, E., "Flexural Capacity of Fiber Reinforced Concrete with a Consideration of Concrete Strength and Fiber Content," Construction and Building Materials, 138, 2017, 222231.

[26] Bao, J., Zhu, Z., Tong, M., Yin, Y. and Peng, Y., “Influence of Braking Pressure on Tribological Performance of Non-Asbestos Brake Shoe for Mine Hoister During Emergency Braking," Industrial Lubrication and Tribology, 64, 4, 2012, 230-236.

[27] Omrani, E., Menezes, P. L. and Rohatgi, P. K., "State of the Art on Tribological Behavior of Polymer Matrix Composites Reinforced with Natural Fibers in the Green Materials World," Engineering Science and Technology, an International Journal, 19, 2, 2016, 717736.

[28] Aranganathan, N., Mahale, V. and Bijwe, J., “Effects of Aramid Fiber Concentration on the Friction and Wear Characteristics of NonAsbestos Organic Friction Composites Using Standardized Braking Tests," Wear, 354-355, 2016, 69-77.

[29] Blau, P. J. and McLaughlin, J. C., "Effects of Water Films and Sliding Speed on the Frictional Behavior of Truck Disc Brake Materials," Tribology International, 36, 10, 2003, 709-715.

[30] Stachowiak, G. W. and Batchelor, A.W., "Engineering Tribology," Butterworth, Heinemann, Woburn, 2001, 644 